\title{
New Directions on Old Connections: Body/Soul, Flesh/Spirit, Self/Other
}

\author{
Donald Capps • Nathan Carlin • Robert C. Dykstra
}

Published online: 10 February 2013

(C) Springer Science+Business Media New York 2013

The articles in this special issue of Pastoral Psychology were presented as working papers at the fourth annual conference of the Group for New Directions in Pastoral Theology, which took place at Princeton Theological Seminary in Princeton, New Jersey on October 17-19, 2012. The papers presented at the three preceding conferences were published as articles in Pastoral Psychology (December 2010, June 2011, and August 2012). We are deeply indebted to Lewis Rambo, editor of Pastoral Psychology, for enabling us to publish the articles as a group. As our group continues to meet, we have an increasing sense that we are, in fact, a group - one in which we learn from one another.

As in previous years, this conference had a theme: "New Directions on Old Connections: Body/Soul, Flesh/Spirit, Self/Other." Our themes emerge from the concluding discussion of the previous year's meeting in which participants are invited to propose the next year's theme. Often, we have several proposals and these typically arise from our discussions of papers that have been presented. This year's theme, however, emerged from a conversation that occurred in the minivan that several participants rode in together en route to Union Theological Seminary in Richmond, Virginia, the locus of our 2011 annual conference, a discussion that focused on the fact that Christianity has historically tended to emphasize the soul and the spirit (sometimes using these terms interchangeably) at the expense of the body or "the flesh." Yet, the church has also understood itself as "the body of Christ." When this discussion was presented to the other group members, there was general (although not unanimous) agreement that this could be the theme for the 2012 conference, with the proviso that we also include the relationship of "self" and "other," thus affording members of the

D. Capps • R. C. Dykstra

Princeton Theological Seminary, PO Box 821, Princeton, NJ 08542-0803, USA

D. Capps

e-mail: cappsdonald@aol.com

R. C. Dykstra

e-mail: Robert.Dykstra@ptsem.edu

N. Carlin $(\bowtie)$

The University of Texas Medical School, Houston, TX 77030, USA

e-mail: nathan_carlin@yahoo.com 
group the freedom of not focusing their papers on the body/soul or flesh/spirit topic if they were not disposed to do so. Put more positively, it was felt by many of us that the self/other dichotomy is also deeply rooted in Christian history and tradition.

It is noteworthy that some authors focused their papers on the physical body of Jesus. For example, Nathan Carlin explores the adaptive effects of the born-again experience of Kevin Kelly (founder of Wired magazine) who was in Jerusalem on Easter eve, 1979, and slept throughout the night in the Church of the Holy Sepulchre on the marble slab where Jesus was believed to have been crucified; Jaco Hamman focuses on Gospel accounts of Jesus' temptation in the wilderness during forty days of fasting (Mark 1:12-13; Matthew 4:1-11; Luke 4:1-13; see also Hebrews 2:18, 4:15) as illustrative of what psychoanalyst Adam Phillips (2010) calls "getting away with it" experiences; and Ryan LaMothe discusses the politically subversive nature of the Christian affirmation of the physical resurrection of Jesus Christ.

Other authors focus on aspects of the physical body: Kirk Bingaman employs recent findings in the neurosciences to discuss the role of spiritual practices in positively affecting the functioning of the human brain; and Donald Capps considers the embarrassment that American illustrator Norman Rockwell experienced concerning his protruding Adam's apple.

Four authors-Carol Cook, Carrie Doehring, Barbara McClure, and Bonnie MillerMcLemore-address the theme of embodiment from an explicitly pastoral and/or practical theological perspective. They emphasize the fact that pastoral and/or practical theology tends to accept the very challenge that the Christian tradition poses for contemporary theology, that of giving the body in all of its complexities a fair hearing in discussions of the body/spirit relationship. Thus, Carol Cook demonstrates in her article on a seminary course that she co-taught that we cannot simply view the human individual from a cognitive perspective alone. We must take into consideration the fullness of the human body, which includes its emotions and passions, especially in discussions of issues on which liberals and conservatives have strong disagreements. Carrie Doehring also describes a seminary course that she offered which drew students' attention to the need for connecting body and spirit by integrating an authentic spirituality into their daily experiences of coping with stress. She presents a spiritually-oriented model that emphasizes the defining of one's values and identifying a keystone habit which students see the need to change. (Readers will note significant commonalities between the articles by Kirk Bingaman and Carrie Doehring.) Barbara McClure considers a familiar claim of many today who say they are "spiritual but not religious" and explores how religious ritual may serve as a means to ground or reembody spirituality for a new generation. And Bonnie Miller-McLemore raises the question whether religion scholars, including those who write and speak about embodied knowing or embodied theology, have paid sufficient attention to actual bodies. She focuses on what practical and pastoral theologians can learn from recent research on evolution, biology, and bodies in anthropology as well as the biological sciences.

Finally, four of the articles take up the self/other relationship and its vicissitudes: Robert Dykstra discusses a seminary course in which he used the young adult novel Speak by Laurie Halse Anderson (1999) to explore the importance of non-shaming pastoral conversations around sensitive adolescent sexual concerns. Gregory Ellison (together with his coauthor Hashim Pipkin) offers an interdisciplinary exploration of rage in light of the social context of many young African American men. Jay-Paul Hinds, showing that "the pen is mightier than the sword," focuses on the writings of Richard Wright and the struggles of his protagonists to deal with and overcome dispiriting self-perceptions. And Carol Schweitzer explores the courage of the monks of Tibhirine in light of the psychological theories of Heinz Kohut and Julia Kristeva. Like several others, she focuses on the role of the seminary professor, in this case that of teaching seminary students about other (i.e., non-Christian) religious traditions. Our discussions 
of these four working papers in particular led to our decision to focus, in our 2013 conference, on the theme: "Emotion, Mood and Temperament."

The reader of these articles will discover that the fact that many of the authors are professors in theological schools plays a major role in some authors' reflections on the theme of body/soul, flesh/spirit, self/other. Carol Cook, Carrie Doehring, Robert Dykstra, Gregory Ellison, and Carol Schweitzer make explicit reference to their engagement with theological students. Also, some authors reveal or intimate that their choice of topic was inspired by their own personal experiences. As participants in the discussion of the working papers, we three can testify to the fact that all of the participants wrote on topics that were of deep personal interest, and this, we believe, is one of the hallmarks of those who identify themselves as pastoral theologians, i.e., that their writings are not, for them, merely academic. This may itself be quite remarkable in light of the fact that virtually all of the participants in the conference are professors associated with academic institutions. ${ }^{1}$

We have noted in previous prefaces to special issues of Pastoral Psychology that the number of participants that the conference setting and format is able to accommodate is necessarily limited, but the publication of these articles gives expression to our felt sense that when we gather together other colleagues in pastoral theology are present with us. This, of course, includes not only colleagues who are living but also colleagues who have joined that great cloud of witnesses of which the author of Hebrews speaks (12:1). We have also noted in previous prefaces that our search for "new directions" in pastoral theology is a non-exclusive venture. In fact, we believe that one of the noteworthy features of pastoral theology - and of those of us who identify ourselves as pastoral theologians - is that it is - and we arecontinually in search of "new directions."

\section{References}

Anderson, L. H. (1999). Speak. New York: Puffin Books (Penguin).

Phillips, A. (2010). On balance. New York: Farrar, Straus, and Giroux.

\footnotetext{
${ }^{1}$ To bring this special issue of Pastoral Psychology to a fitting closure, we have included here a sermon which was preached by Nathan Carlin at St. John's Church of Houston, Texas, on January 27, 2013. Our conference theme - body/soul, spirit/flesh, self/other - is clearly reflected in this sermon because it is based on several verses in Paul's first letter to the church in Corinth (i.e., 1 Corinthians 12:12-27) in which Paul discusses the Body of Christ. We believe that this sermon is illustrative of the fact that sermons are often expressions of pastoral theology. This is because sermons, while inherently theological, are also pastoral. That they are pastoral is reflected in the fact that they are addressed to specific audiences and focus on matters that the preacher discerns to be of existential concern, both collectively and individually, for those whom the preacher is addressing.
} 